
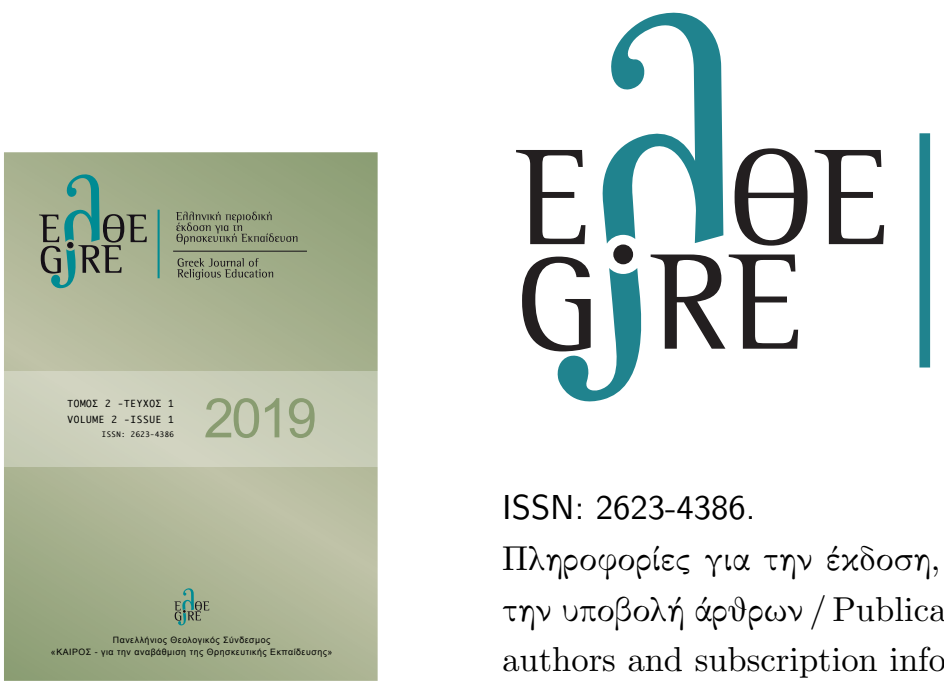

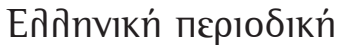

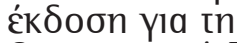

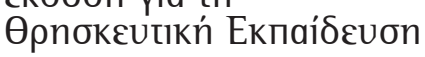

Greek Journal of

Religious Education

ISSN: 2623-4386.

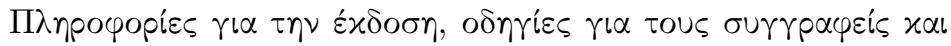
$\tau \eta \nu$ u $о \beta \circ \lambda \eta \dot{~ \alpha ́ p \vartheta \rho \omega \nu ~ / ~ P u b l i c a t i o n ~ i n f o r m a t i o n, ~ i n s t r u c t i o n s ~ f o r ~}$ authors and subscription information: http://www.gjre.gr

\title{
Espousing a more inclusive curriculum for Roman Catholic religious education in the United States: toward a catholic worldview
}

William Joseph Mascitello*

*Assistant Professor, Felician University, Lodi, NJ, USA

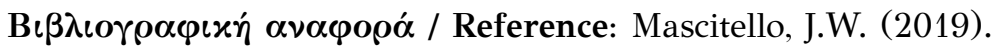

Espousing a more inclusive curriculum for Roman Catholic religious education

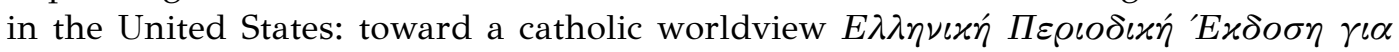
$\tau \eta \Theta \rho \eta \sigma \varkappa \varepsilon v \tau \iota \varkappa \dot{~ E \varkappa \pi \alpha i \delta \varepsilon v \sigma \eta ~ / ~ G r e e k ~ J o u r n a l ~ o f ~ R e l i g i o u s ~ E d u c a t i o n, ~ 2(1), ~ 53-60, ~}$ DOI: $10.30457 / 30420194$

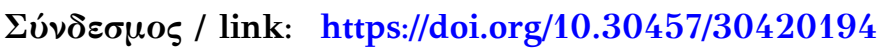

'O

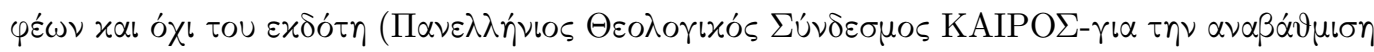

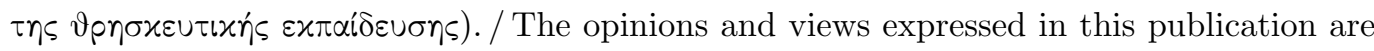
the opinions and views of the authors and not of the publisher (KAIROS - Greek Theological Association for the improvement of the Religious Education).

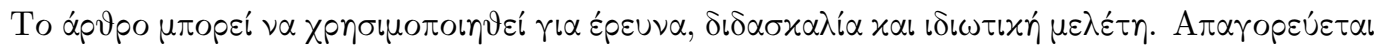

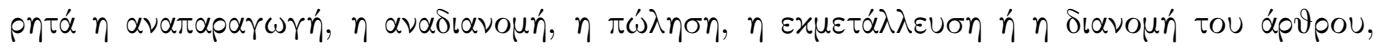

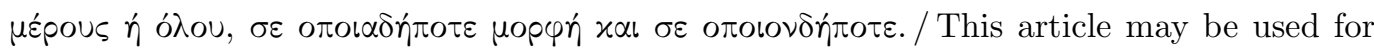
research, teaching, and private study purposes. Any substantial or systematic reproduction, redistribution, reselling, licensing or distribution in any form to anyone is forbidden.

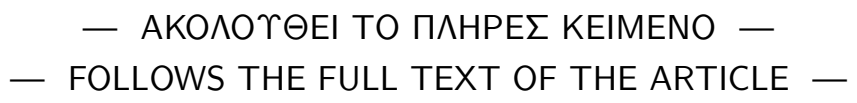




\title{
Espousing a more inclusive curriculum for Roman Catholic religious education in the United States: toward a catholic worldview
}

\author{
William Joseph Mascitello* \\ *Assistant Professor, Felician University, Lodi, NJ, USA
}

\begin{abstract}
The author hopes this effort will help to promote the understanding that Religious Education (RE) efforts in the United States would benefit from an expanded curriculum moving toward a truly inclusive catholic worldview. A Roman Catholic who writes from the perspective of citizen of the United States and student of the public education system through secondary school, the author advocates for incorporation of an expanded curriculum in Catholic Christianity, one which would embrace RE efforts in the public sphere. This reorientation of RE would allow the Church to be ever-increasingly open to - and informed by - the voices of all persons, including those previously marginalized. Such orientation is based onand reciprocally promotes - recognition of the fullness of the human dignity of all persons. A more comprehensive curriculum takes into account that authentic RE cannot be solely an intramural affair. A worldview which is truly catholic is fully open to the perspective to the other; and the resultant mutual enrichment and understanding can move participants to be much needed instruments for peace in the world.
\end{abstract}

Key words: Informed worldview, Roman Catholic Religious Education, United States.

\section{Introduction}

Elsewhere, I have explored an approach for Roman Catholic Religious Education (RE) which is more holistic than those typically in place in the United States. Such an approach strives for a fully-realized human potential and eschews polarizing so-called religious and secular dimensions of human existence, a false dichotomy found in post-Enlightenment Christianity in the West (Mascitello, 2015, p. 110). A more comprehensive curriculum recognizes the contributions of all the dimensions of life in its various stages which contribute to the formation of a worldview for the Christian practitioner (p. 203).

In the United States, the majority of children attend public schools, and the population of Catholic schools continues to decline. Supplemental RE programs, sometimes called faith formation, are offered for Roman Catholic children at the local level, generally at parish churches. These programs are scheduled at times outside of compulsory public education and thus have come to be considered extra-curricular. These supplemental 
parochial efforts generally end with the celebration of the Confirmation of the child, at some time between the sixth and tenth grades. Incorporation of RE into the curriculum of public schools would allow participants to expand their worldviews via clarification of their own views and dialogue with those of other perspectives. The worldviews of these young people would expand as they are open to- and informed by - the voices of all persons, including those previously marginalized (Sporre, 2010, pp. 72-73).

\section{The Public Sphere}

The founders of the United States recognized the importance of principle of separation of church and state for the newly formed republic. Although the use of church-state language was introduced by founding father Thomas Jefferson in 1804, the term was not utilized much in the United States until the late nineteenth century (Moran, 2016, p. 223). The institutions of church (specifically for the scope of this article the Roman Catholic Church) and state have had an ambivalent relationship throughout the history of the United States. Compulsory formal education has been contextualized by this relationship, as outlined by Steven K. Green, who notes that by the nineteenth century in the United States:

In public education, the notion of nonsectarian instruction went through several stages, with many school districts minimizing the religious content of the exercises in response to complaints by Catholics, Jews, and other religious minorities. A handful of state courts even struck down the religious exercises as being inconsistent with separation of church and state. By late century, many Protestant leaders complained that public schools were being "secularized." In contrast, a growing number of educators, intellectuals, and freethinkers commended the changes to public education, calling for a more rigorous application of church-state separation (Green, 2014, p. 12).

The American Civil Liberties Union (ACLU) defines itself as an organization which preserves the rights of individuals as the "guardian of liberty, working in courts, legislatures, and communities to defend and preserve the individual rights and liberties that the Constitution and the laws of the United States guarantee everyone in this country" (About the ACLU). Staunch defenders of the Establishment Clause of the Constitution of the United States, the ACLU nevertheless affirmed the value of promoting the understanding of religions and published the Joint Statement of Current Law on Religion in the Public Schools, which has been ratified by several dozen religious organizations. The document summarizes the current understanding that publicly-funded schools have not been declared by the courts as "religion free zones" (Joint Statement, Introduction). Schools may teach about religion, and include such considerations as the influence religion has had on the advancement of civilization through the arts (pp. 5-6). The teaching about religion and its influences must be mutually exclusive from the teaching of - or advocacy for - any religion or religious practice. The teaching of values fits this schema, especially with regard to "civic virtues" such as good citizenship, honesty, and respect. Other values may be taught including sexual abstinence and contraception, as the "fact that most, if not all, religions also teach these values does not make it unlawful to teach them" (p. 16). 
Having experienced discrimination while growing up as a Jew in a predominantly Christian area, Linda K. Wertheimer became an advocate for the teaching about religion in public schools. Her advocacy is disclosed in the title of her 2015 work Faith Ed.: Teaching About Religion in an Age of Intolerance in which she dismisses anecdotal evidence refuting the benefit of RE in the public sphere. Among the stories she recounts is that of an incident which became known as "Burkagate" which involved a teacher in the United States who introduced her students to garb from Middle Eastern cultures found in Kuwait, Saudi Arabia, and Afghanistan as an exercise in mutual understanding. Some of her students donned the garb and posted pictures wearing it on social media. The teacher was forced into retirement after her extensive teaching career came under attack with a flurry of e-mails accusing her of "corrupting children and attempting to convert them to Islam" (Wertheimer, 2015, p. 2).

Wertheimer recounts undercurrents of support for bridging the gap between the public sphere and religion in the middle of the twentieth century driven by reports issued by the American Council on Education and the words of Supreme Court Justice Tom C. Clark in a decision regarding the removal of prayer from public schools. Clark's response to those who held that public education in the United States was advancing a religion of secularism was that in practice, religion in schools must not be treated with hostility. Incorporation of RE in schools is an important part of a well-rounded curriculum, since "It might well be said that one's education is not complete without a study of comparative religion or the history of religion and its relationship to the advancement of civilization" ( $c f$. Wertheimer, 2015, p. 164).

In support of her promotion of at least an understanding of various religious worldviews, Wertheimer recounts RE efforts in the community of Modesto, California where a course on world religions was introduced subsequent to meetings held with religious leaders regarding advocacy for gay rights after a bias incident in the community (162ff). Extolling the successes in Modesto and some other efforts in her chapter four Raising Religiously Literate Americans, Wertheimer notes that these efforts have led to observable measures of increase in tolerance and understanding of diversity (pp. 181184). In 2014, lawmakers in California recommended that all public school districts in that state adopt the Modesto RE model. Apparent success of the model and legislative advocacy for it notwithstanding, there is a general lack of implementation of RE efforts in California and in the public sphere in general throughout the United States (p. 185).

That RE is rarely seen as a component of public compulsory education in the United States differentiates the educational experience in the United States from many other nations. Within the curriculum in the United States, references to religion sometimes appear within discussions about the humanities, history, or other subjects. However, the ongoing reality is that reference to religion and its influences offer a marginalized appropriation of religious thought, belief, and practice within public schooling curriculum. Advocates for compulsory RE tend to see their advocacy as a response to the call for expanded worldviews, encompassing greater understanding and tolerance among people with various religious understandings. Such a response is offered by Marios KoukounarasLiagis via his Compulsory Religious Education: A Justification Based on European Experience. Koukounaras-Liagis posits that RE is "indispensable to a contemporary curriculum 
that helps students to cope with the world they live in, and one in which religious practices and beliefs need to be comprehended" (Koukounaras-Liagis, 2012, p. 44). He submits that full state control over the content-where religious organizations have limited advisory roles - should alleviate concerns about proselytizing. Other qualifiers are offered which make the idea more tenable to educators in the United States. RE in the public sphere must be a fully enlightened, pluralistic, post-modern, student-centered constructivist approach (p. 47).

John Valk identifies a factor which further contributes to the de-emphasis of RE in the public sphere, the distancing of the academic world from theological studies, especially in the West. The move toward secularization in many institutions is advanced by the dissociation of institutions from their religiously-founded roots. Additionally, there is a tendency to compartmentalize disciplines which has distanced them from one another and certainly from expansive considerations of ultimate meaning (Valk, 2010, pp. 104-106).

Valk's position is that the more inclusive term of worldview should be used to supplant religion in order to include those who have no inclination toward religious sensibilities. Sufficiently interdisciplinary, worldview education endeavors to incorporate both secular and religious perspectives while rejecting "the secular notion that religious beliefs can be relegated to the private sphere" (p. 107). Perhaps ideas from Valk and those he cites can inform efforts in the public sphere in the United States to allay fears of proselytizing of students via public RE efforts.

\section{Efforts within the Roman Catholic Church}

Religious educator Gabriel Moran begins consideration of the current state of RE by musing over whether Roman Catholic (and other) religious leaders have a true understanding of what RE in the world today entails (Moran, 2016, p. 214). Moran traces the history of the term Religious Education as a modern construct evolving from a Unitarian usage in the nineteenth century. Within Roman Catholicism, the emphasis has been on Catholic Education, an effort promoted through its Catholic parochial school system (p. 217). Those who did not attend Catholic schools attended supplemental sessions sponsored by the Confraternity of Christian Doctrine (CCD) which were generally in a similar format to Protestant Sunday School models. Without proper emphasis and funding, CCD efforts foundered. Generally scheduled outside of the times of compulsory state-sponsored education, these efforts tend to be considered "extra-curricular" rather than an important component of a student's educational curriculum. The term Religious Education eventually took hold in Roman Catholicism and is still widely used; however, it is often directly identified with CCD and its shortcomings, and thus lacks the multivalent sensibility it enjoys elsewhere in the world, especially England and other Englishspeaking countries (p. 218).

Moran advocates a re-contextualization of RE which would require Catholicism as an institution to allow the term to evolve, to "make a jump from an intramural meaning of religious education to a meaning in which the Roman Catholic Church would be tested by interaction with other religions and with secular society" (p. 219). 
He specifically identifies a lag in the promotion of interreligious education in the United States as compared to Europe.

Regarding formal education efforts during the years of compulsory state schooling, Moran promotes understanding religion by ensuring the treatment of religion as its own discipline. Perhaps efforts for the understanding of religion within compulsory education can augment RE for Roman Catholics. This idea has been disparaged by Roman Catholics since the Church's nineteenth-century efforts to remove RE from the public sphere. However, such efforts arguably work toward a more comprehensive RE which would begin to stir up "the breadth and depth of intellectual excitement" ( $p$. 229). The ideals identified by Moran are not priorities in parish-based RE programs. Local RE efforts are generally not prepared for understanding of and dialogue with other religions. However, interreligious efforts in the public sphere can fill in the gaps within Roman Catholic RE efforts, as participants work towards being religiously educated (p. 226) via their engagement with those considered as other.

\section{Conclusion}

A more expansive approach for RE in the United States would allow for cooperation between and incorporation of efforts from both the public and private spheres. Such an approach would necessitate a thoughtful reconsideration of the state of RE in both domains. Within public education, a bias against religious sensibility is perpetuated by several factors including the misunderstanding and misapplication of the term separation of church and state. Internally, Roman Catholicism's approach to RE for its children who attend public schools (the vast majority) is often considered inadequate. This consideration is reasonable insofar as the Church's efforts are supplemental, extracurricular, and intramural/closed to adequate consideration of and interaction with the other.

For the Catholic Church in the United States, a more expansive approach to RE for most of its young people would call for the continuation of local/parish efforts while embracing the introduction of RE into the curriculum of the public schools. The worldviews of religiously educated young citizens would be informed by both faithspecific (albeit intramural) local efforts, as well as the encounter with those from other religions and worldviews in the public forum. Such an approach is valued by religious educators and has been considered as indispensable in Europe. The expanded enterprise acknowledges the importance of one's own perspective, which is consistently being formed and re-formed in relation to and in dialogue with the other toward a worldview which is truly catholic.

\section{Notes}

1. A National Center for Education Statistics (NCES) report indicated that in 2015, 2,088,000 (3.6\%) of children through grade twelve attended Catholic schools in the United States. Current statistics offered by the National Catholic Education Association (NCEA) indicate that the number has decreased to $1,835,376$.

2. A report issued based on a 2015 survey by the Center for Applied Research 
(CARA) indicates that $62 \%$ of parents who identified as Catholic had not enrolled their children in either supplemental parish-based RE or Catholic school, for Hispanic parents the percentage was higher at $72 \%$.

3. The Establishment Clause is found the First Amendment of the Constitution of the United States and prohibits government interference in freedom of religion by forbidding the legislature to make any law "respecting an establishment of religion, or prohibiting the free exercise thereof" (cf. The Bill of Rights - the first ten amendments of the Constitution of the United States. Retrieved from https://www.archives.gov/ founding-docs/bill-of-rights-transcript in 12/11/18

4. Among the advocates for allowing participants to shape the educational curriculum so that public education might more adequately reflect their own experiences while moving from what he terms the "technical value system" is Dwayne E. Huebner. See especially his "Curricular Language and Classroom Meanings," in The Lure of the Transcendent: Collected Essays by Dwayne E. Huebner, ed. Vikki Hillis (1999).

5. Notably Jackson, R. Miedema, S., Weisse, W., and Willaime, J. Religion and education in Europe: Developments, context, and debates. New York, NY. 2007. Valk indicates that Jackson, et al advocate for neither a confessional nor a non-conformist notion of worldview, but a "mixed system" or "interreligious model" (Valk, 2010, p. 106) so that religious views would neither be excluded nor required when determining what worldview education entails.

6. The struggle against RE in the public sphere by Roman Catholics in the United States is directly related to the bias they encountered as immigrants to the United States in the nineteenth century, and has been well documented. In one account from the biography of Archbishop John Hughes (the first Archbishop of New York) Henry A. Brann recounts the situation in the public schools of this era:

...the teachers, who were all Protestants, made comments on the text unfriendly and insulting to Catholic convictions. Protestant hymns were sung, and Protestant prayers, expressing Protestant doctrines, were recited. The whole tendency of this system of education was to make Catholic children indifferent to their religion or apostates from it (Brann, 1892, p. 69).

\section{References}

American Civil Liberties Union (ACLU). About the ACLU. Retrieved from https://www.aclu.org/aboutaclu?redirect=about

American Jewish Congress. (1995). Joint Statement of Current Law on Religion in the Public Schools. Retrieved from https://files.eric.ed.gov/fulltext/ED387390.pdf

Bill of Rights. The first ten amendments of the Constitution of the United States. Retrieved from https://www. archives.gov/founding-docs/bill-of-rights-transcript

Brann, H. A. (1892). Most Reverend John Hughes: First Archbishop of New York. New York: Dodd, Mead and Company.

Center for Applied Research/CARA. (2015). The U.S. Catholic Family: Demographics. Retrieved from https:// 
cara.georgetown.edu/staff/webpages/Catholic\%20Families\%20Demographics.pdf

Green, St. K. (2014). The Separation of Church and State in the United States. In The Oxford Research Encyclopedia of American History. Retrieved from http://oxfordre.com/americanhistory/view/10.1093/ acrefore/9780199329175.001.0001/acrefore-9780199329175-e-29?print=pdf.\%20doi:\%2010.1093/ acrefore/9780199329175.013.29

Groome, Th. H. (1998). Educating for Life. Allen, TX: Thomas More.

Huebner, D. E. (1999). Curricular Language and Classroom Meanings. In V. Hillis (Ed.), The Lure of the Transcendent: Collected Essays by Dwayne E. Huebner (pp. 101-117). Mahwah, NJ: L. Erlbaum Publishers.

Koukounaras-Liagkis, M. (2012). Compulsory Religious Education: A Justification Based on European Experience. In Shoniregun, C. A. \& Akmayeva, G. A. (Ed.), Ireland International Conference on Education, 2012 Proceedings (pp. 44-48). Dublin, Ireland: Infonomics Society.

Mascitello, W. J. (2015). Theosis: Union with God as a foundation for religious education in Roman Catholicism. Retrieved from http://citeseerx.ist.psu.edu/viewdoc/download?doi=10.1.1.904.5220\&rep=rep1\&type=pdf

Moran, G. (2016). Missed Opportunities: Rethinking Catholic Tradition. Bloomington, IN: iUniverse.

National Catholic Education Association/NCEA. (2018). Catholic School Data. Retrieved from https://www. ncea.org/NCEA/Proclaim/Catholic_School_Data/Catholic_School_Data.aspx

Sporre, K. (2010). Gender and Religion, and Religious Education. In K. Sporre \& J. Mannberg (Ed.), Values, Religion and Education in Changing Societies (pp. 67-74). New York: Springer Publishing.

Wertheimer, L. K. (2015). Faith Ed. Teaching About Religion in an Age of Intolerance. Boston, MA: Beacon.

Valk, J. (2010). Worldviews of Today. In K. Sporre \& J. Mannberg (Ed.), Values, Religion and Education in Changing Societies (pp. 103-120). New York: Springer Publishing.

William J. (Bill) Mascitello completed a master's degree in Theological Studies at the University of Notre Dame and his doctorate in Religion and Religious Education at Fordham University. His dissertation Theosis: Union with God as a foundation for religious education in Roman Catholicism discusses a reorientation of RE efforts for Roman Catholicism. Dr. Mascitello is currently Assistant Professor and Director of the fully-online Master of Arts in Religious Education (MARE) Program at Felician University in Lodi, New Jersey in the United States. Bill has taught within schools and directed local parish RE efforts within the Archdiocese of Newark (New Jersey/U.S.A.) for several years. 
